\title{
Relationships are building blocks to social justice: Cases of biblical justice and African Ubuntu
}

\begin{tabular}{|c|c|}
\hline $\begin{array}{l}\text { Author: } \\
\text { Selaelo T. Kgat }\end{array}$ & \\
\hline $\begin{array}{l}\text { Affiliation: } \\
{ }^{1} \text { Department } \\
\text { and Science o } \\
\text { Faculty of The } \\
\text { University of } \\
\text { South Africa }\end{array}$ & $\begin{array}{l}\text { f Missiology } \\
\text { Religion, } \\
\text { logy, } \\
\text { retoria, }\end{array}$ \\
\hline $\begin{array}{l}\text { Project leade } \\
\text { Project numb }\end{array}$ & $\begin{array}{l}\text { S.T. Kgatla } \\
\text { er: } 04486863\end{array}$ \\
\hline $\begin{array}{l}\text { Description: } \\
\text { This research } \\
\text { project, 'The } \\
\text { Churches in th } \\
\text { apartheid in S } \\
\text { directed by Pr } \\
\text { Kgatla, Depart } \\
\text { Missiology an } \\
\text { Religion, Facu } \\
\text { University of }\end{array}$ & $\begin{array}{l}\text { s part of the } \\
\text { ole of German } \\
\text { e demise of } \\
\text { uth Africa', } \\
\text { f. Dr Thias } \\
\text { ment of } \\
\text { Science of } \\
\text { ty of Theology, } \\
\text { retoria. }\end{array}$ \\
\hline $\begin{array}{l}\text { Correspondin } \\
\text { Selaelo Kgatla } \\
\text { thias.kgatla@ }\end{array}$ & $\begin{array}{l}\text { author: } \\
\text { p.ac.za }\end{array}$ \\
\hline $\begin{array}{l}\text { Dates: } \\
\text { Received: } 03 \\
\text { Accepted: } 17 \\
\text { Published: } 28\end{array}$ & $\begin{array}{l}\text { lov. } 2015 \\
\text { Mar. } 2016 \\
\text { Oct. } 2016\end{array}$ \\
\hline $\begin{array}{l}\text { How to cite th } \\
\text { Kgatla, S.T., } 20 \\
\text { 'Relationships } \\
\text { blocks to socia } \\
\text { of biblical just } \\
\text { Ubuntu', HTS } \\
\text { Studies/Theol } \\
72(1) \text {, a3239. } \\
\text { org/10.4102/I }\end{array}$ & $\begin{array}{l}\text { is article: } \\
16, \\
\text { are building } \\
\text { I justice: Cases } \\
\text { ce and African } \\
\text { eologiese } \\
\text { gical Studies } \\
\text { tttp://dx.doi. } \\
\text { ts.v72i1.3239 }\end{array}$ \\
\hline $\begin{array}{l}\text { Copyright: } \\
\text { (C) 2016. The } \\
\text { Licensee: AOS } \\
\text { is licensed un } \\
\text { Creative Comr } \\
\text { Attribution Lic }\end{array}$ & $\begin{array}{l}\text { uthors. } \\
\text { S. This work } \\
\text { ler the } \\
\text { lons } \\
\text { ense. }\end{array}$ \\
\hline Read online: & \\
\hline 口乎回 & $\begin{array}{l}\text { Scan this QR } \\
\text { code with your } \\
\text { smart phone or } \\
\text { mobile device } \\
\text { to read online. }\end{array}$ \\
\hline
\end{tabular}

The entire Bible is full of themes calling humans to live justly with one another and fear God who is the author of justice. The first book of the Bible, Genesis, carries the story of God's relationship with his people. Their relationship is bound by social justice and mutual love in reciprocity. This article argues that African Ubuntu has an affinity with the Bible's message of justice and mutual caring for one another. Ubuntu presupposes that humans were created in God's image and indicates that characteristics such as kindness, charity, equality, love of one's neighbours and voluntarily dispensing justice to others are present in human life. God created humans to be bound to one another in caring love, coexistence and total dependence. In today's world, social justice requires good judgement from those who are in privileged positions to implement it.

\section{Social justice: An innate human quest for fullness of life}

Human beings were created by God as creatures who have relationships among themselves and with God (Smith 1864). Their relationship was to be regulated by loving one another and promoting equality and peace among themselves. After sin had entered and distorted their harmonious relations, humans became self-centred and loved themselves as themselves. Kindness to the poor, the needy and the sick which was regulated by the spirit of God dissipated with the coming of sin. In all societies of the world, some sparks of this original nature of humanness remained and guided their relationships (Packer 2013:1). In South Africa, it was called Ubuntu.

Over the years, in its missionary endeavours to 'Christianise' black people in Africa, the church did more harm in the area of social relations and justice than it intended to. In some areas, the 'Christian Crusades, civilisation and colonisation of African people' led to a distortion of scripture of basic human relations and social justice. Accompanied by the colonial view of the right of conquest and seizure of land from black people, Christianity lost some of the core of its teachings of the law of Christ's love and the promotion of good neighbourliness. Because of white racial supremacy and dominion over black people, the 'civilisation' of Africa was seen as the ultimate development of the human race in South Africa; more harm than good was done in the area of social justice (Johnson 1994:2). With self-imposed supremacy with the right of conquest and acquisition of land as a means of gaining title to territory from Africans, racial dominance in all spheres of society became the norm and the basic tenets of Christian love were irrevocably annulled.

The resultant, relentless resistance to the system by African people further eroded social relations as those who came to power in turn denied their people what they fought for together. Some black leaders continued the same injustices which were meted to them by their former oppressors. In the colonial era, inequality was defined by racism and in the new dispensation it is defined by corruption, unemployment and elitism.

During the apartheid era, Christianity, as it came to be maintained and understood by most white people in South Africa, had nothing to do with social justice and coexistence. Faith in God meant avoiding political issues and leaving them to the ruling party while focusing on the 'matters that would take one to heaven'. A form of Christian escapism theology was developed as it was sponsored by white piety and worldwide Pentecostalism which promised salvation without social justice. According to Worden (2012:73), the white-engineered social order shaped by political and social white interest fundamentally destroyed Christian tenets of love, justice and mercy. Many black people, because of the dominant religion and culture that controlled access to prosperity and a means of production, had to conform for fear of repression and ridicule. They were ridiculed as 'heathen, barbaric, backward and uncivilised' if they did not embrace the white 
person's religion. Although South Africa was called a Christian country, in essence it denied its power. Paul's metaphor '... holding to a form of godliness, although they have denied its power' (2 Timothy 3:5) applied to the situation.

This article proposes that biblical relationships (which have earing to the concept of Ubuntu) premised in social justice should help to create a new community that is transformed and empowered to embrace equality and justice in South Africa. To this notion of social justices, which has its roots in the biblical message, I extrapolate that with African Ubuntu it can point to a paradigm that could be applied to South Africa to arrest the spiral of unbridled societal destruction. The concept of African Ubuntu is introduced to argue that humanness is something that is engraved in all human consciousness although in some communities, such as that of African descent, it is more pronounced. In South African communities, which are embroiled in bitterness and violence that lack models of how to emancipate themselves from social problems, Ubuntu can serve as a model of understanding 'loving connectedness' so as to get out of entanglement. Ubuntu is mostly pronounced in African idiomatic expressions that can serve as indicators of better human relations. South Africa with its morass and endemic problems of inequality, injustice, corruption and crime mainly resulting from mediocre rule with its resultant acute violence and low-intensity revolution - needs a turnaround strategy that would save it from total destruction.

\section{Ubuntu defined}

The problem with the interpretation of the concept of Ubuntu by some scholars is that they try to relate it to a foreign context that it does not fit in. For example, Ramose (2001:1) tries to apply the concept of Ubuntu to a conception of law. The African concept of law does not mix with Western law. Roman law postulates that a person is not guilty until proven guilty in terms of elaborate and buzzer Western legal procedures. In contrast, justice in Africa is understood as safeguarded by metaphysical reality. Similarly to Christians, they believe that God is a supreme being who determines justice, upholds and dispenses it. People have a common origin and have the same destiny. The fact that they are created by the same being who is the supreme omnipotent judge works through their consciences so that they know what is good and right. When people commit a crime, they are responsible for that crime; because through their intuition they know it is not right to commit crime.

Ubuntu revolves around fairness and justice. They believe that the creator wants a restoration of equilibrium and maintenance of symmetrical relationship, and so these are the ideals they strive for. All biological human beings have a burden to live responsibly with regard to their neighbours, regardless of their creed, religion and colour. To regard another person as non-person because they are perceived to be lacking rationality as Aristotle postulated in his definition of human being is absurdity (in Ramose 2001:3).
The problem with the use of the term Ubuntu in South Africa is that it is perceived as, more often than not, opportunistic, melancholic, romantic and adventurous. In South Africa, Ubuntu was included in the interim constitution (Ramose 2001:4) and often quoted by those abused human rights to induce aggrieved families to forgiveness and abandonment of their demands (ibid). Ubuntu was also used by the Truth and Reconciliation Commission to present Africans as the most forgiving people and thus entice the white culprits to disclose their crimes. Frustrated by the level of brutal death, rapes, arson and self-destruction that are engulfing the country, some leaders evoke a melancholy of primordial order to call on perpetrators of evil that Africans have the ability to rise above the morass disorder and live more decently. Still some leaders evoke Ubuntu in order to romanticise the African people who were living harmoniously before the white people set their foot on the continent. They argue that everything went bad because of the legacy brought by the colonial masters on the continent.

Another approach to defining Ubuntu is clusterism. Scholars such as Gade (2012:484) (2012:484) cluster the definition of Ubuntu into two broad frameworks: the moral quality of a person and interconnectedness. According to Gade (2012:488), the first cluster defines Ubuntu as a human quality and therefore a moral quality. The second cluster defines Ubuntu as a complex, multi-faceted quality like generosity, hospitality, friendliness and compassion. A concept like Ubuntu cannot be understood in a monolithic way. It can be compared to a river that breaks into tributaries and forms many islands around which its water flows and later converges and forms one big river. The geographical areas where tributaries flow may have soil with different colours, but it converges into one river.

Many nuances that are there in the definitions of Ubuntu refer to one concept which manifests itself and configures different meanings depending on the context. Human morality is lived to foster interconnectedness of community. A philosopher coached in Western thought patterns would find Ubuntu thought difficult to grasp (Kimmerle 2001:5). Many African scholars, in their conversation with Western scholars, try hard to find the language that is accommodative to Western counterparts. To use Descartes' dictum Cogito ego sum cannot be regarded as a true representation of the concept of Ubuntu. Ubuntu in the first instance is the concept that refers to a triangular interconnectedness of humans with their God(s) and land. It is experienced intuitively and corporately. It encompasses the whole life. There is no area of human existence that escapes the permeation of Ubuntu. Ubuntu is not something that refers to people's convenience or privilege to avoid their responsibility and accountability. It refers to the way of life that needs to be beneficial to the whole community as adjudicated by the supernatural beings in whose domain justice and fairness reside. Anyone who breaks the law of Ubuntu disturbs the whole order of things - being in this world and also in the metaphysical world. 


\section{Social justice:A biblical dictum}

Social justice is a biblical theme that runs throughout the whole Bible - from Genesis to Revelation. Crossway (2001:1) cites 69 scriptural portions in the 69 books of the Bible that bear a direct call to social justice. ${ }^{1}$ The first book of the Bible, Genesis, carries the story that humans were created in the image of God so that humans are like God as no other earthly creatures are. The creation stories tell of the special dignity of being human. This underlies the common origin and destiny of humankind (Ogbonnaya 1994:3). Behind the central message of the Bible there is God's call to social justice as humans have a common origin and God's purpose to fulfil in their lives. He has likewise ordained that certain responsibilities belong to humans. It was God's original intention that humans should live in harmony with the laws of God and his purposes (Kane 1978:97). God took humans into partnership with himself and made them his representatives on earth to execute his justice.

Unfortunately, the Israelites (his chosen people for his model) misunderstood their election through Abraham and their exodus from Egypt, and all the privileges and rights that went with it, as their personal privilege that should be exercised only by the Jews. The meaning of neighbour in Leviticus 19:18 meant to them 'their associate'. Consequently, Jews understood a neighbour as a 'member of their community'. The Israelites were to treat such persons fairly and kindly and were not to cheat or rob them. ${ }^{2}$ But their behaviour to non-Jews was such that they did not consider them to be human as Jews were. Jesus came to change this perception. Out of the four Gospel writers, Matthew, Mark, Luke and John, Luke is very clear in his 'retelling' of Jesus' intentions to correct Jewish wrong perceptions of neighbour. Where the Jews understood social justice as doing good only to their fellow Jew, Jesus stood against that assumption and taught that the neighbour, a person who should receive the best in terms of social justice, is not only a blood relative but also a stranger (Lanier 2013:1). According to Luke, Jesus used incidences such as the story of the hated Samaritan ${ }^{3}$ as the hero in matters of social justice. A hated Samaritan is heralded as a hero because he put his life at risk by stopping in the bush where robbers might have been hiding, treating the Jew's wounds, placing him on the Samaritan's own animal with his ceremonially unclean hands, and taking him to a neighbouring inn (Lanier 2013:3). And yet the religious leaders such as the Levites and priests passed by without helping the injured fellow Jew. Jesus exposed and contradicted their legal system and contrasted it with the original purpose of God with regard to social justice.

1.Some Bible books are more explicit about the concept of justice as rooted in relationships. Luke and Acts are examples of these books.

2.The law of Moses taught the Israelites to love their neighbours and do justice to them as they do unto themselves. Life without relationships was inconceivable among the Jews. But the Jews did not realise that their relationships with their neighbour was not only a face-to-face encounter (to own blood relatives) but relationships of mutual affirmation that stretched out to include strangers and the 'others'.

3.A devout Jew would pray and thank God for not creating him a woman or a Samaritan. Samaritans were outcasts who could not be considered as humans as far Samaritan. Samaritans were outcasts who could not be considered as humans as far
as the Jews were concerned. See The Word in Life Study Bible, New Testament as the Jews were concerned. See The Word in Life Study Bible,
Edition, (Thomas Nelson Publishers, Nashville; 1993), pp. 340-341.

\section{Social justice defined}

People are social beings and social relations constitute and determine much of their lives. Individually, they contribute towards the construction or deconstruction of their organisation. Human existence is thus a shared existence and a daily dependence on others is fundamental to living (Fraizer 1975:131). Hence, social relationships and institutions are the bedrock on which human life is anchored and sustained. In every society or organisation there is a power relationship that constrains or enables the individuals to act. There are checks and balances and if balancing (justice) actions are correctly exercised there should be space for all to contribute to the wellbeing of the organisation. The church as an institution is built around these fundamentals of social relations.

In his A Theory of Justice, Rawls (2001:xi) proposes a concept of justice that he calls 'justice as fairness'. According to this concept of justice as fairness, the most reasonable principles of justice are those that would be the object of mutual agreement by persons under fair conditions to strive for. Fairness, as opposite of unfairness, refers to relationships that are enabling and are transformative and empowering at the same time. Social justice as a theory develops from an idea of a social contract (Rawls 2001:xi). It includes basic rights and opportunities, only permitting inequalities in wealth and income that would be to the advantage of the least of all. The social justice, thus, requires good judgement from those who are in power and have to implement it (Wheaton 2009:2).

Wheaton argues that true biblical Christian justice is anchored in God's loving heart (ibid:3). He continues to argue that God has a special interest in the welfare of those at the lowest end of the social ladder: widows, orphans, legal aliens and people living in ghettos and others who are oppressed or excluded. If the church recognises this, it should lead the world in striving for social justice by (1) defining 'social justice', (2) determining key biblical principles of social justice and (3) developing a strong position on any action involving social action to address prevailing social problems (ibid:1).

In the South African context, with all its historical and colonial packages, social justice can only give meaning when it is defined holistically. It should be understood in relation to unemployment, the quality of school education to black people, poorly located and inadequate and limiting infrastructure and resultant corruption, cronyism, nepotism and entitlement mentality. According to Ivor Chipkin (2013), social justice arises when the relationships between groups and social classes are justified on the basis of a more equitable distribution of public and private goods and benefits associated with national and economic growth.

In his address to the tenth World Council of Churches (WCC) assembly, the outgoing moderator Altmann (2013:1) defines social justice as a 'common walk' of fellowship for common destiny (2013:1). In its public statement, the WCC (2013:4) 
defines social justices as seeking common good by confronting privilege, economic injustices, political and ecological exploitations and evil powers that exploit the powerless. Social justice is the capacity to organise with others and to accomplish ends that benefit the whole community (Novak 2009:np). Social justice is about assuring the protection of equal access to rights and opportunities as well as taking care of the least advantaged members of society (Robinson 2014:2). According to Rawls (2001:19), something is just and unjust depending on whether it promotes or hinders equality of access to civil liberties, human rights, opportunities for health and fulfilling lives as well as whether it allocates a fair share of benefits to the least advantaged members of society (2001:28).

Rawls (2001:18) asserts that equality is the most important element of social justice. According to him, equality means a fair distribution of each of the capacities needed to be normal and fully cooperating members of society over a complete life. The fundamental basis for pursuing social justice, according to Wheaton (2009:2), goes back to the fact that every human being is created in the image of God and thus has intrinsic value. In terms of this biblical basis of social justice, all people have a moral duty to help others who are disadvantaged within society. The law of love directly compels Christians to care for anyone in need regardless of their nationality or relationship. The objective of social justice is to cure the unfairness that has occurred and bring about equality and the even distribution of wealth and goods. The United Nations (on 26 November 2007) recognised the need to promote efforts to tackle issues such as poverty, exclusion and unemployment and decided to observe 20 February annually, starting in 2009, as the World Day of Social Justice (2014) (http://www.un.org/apps/news/story.asp).

\section{Ubuntu and Martin Buber 'I-Thou' relationships}

The concept of Ubuntu in the present South Africa has become a buzz word and lends itself to misuse and even abuse. Although it has no equivalent in Western philosophical thought, many Western scholars have entered the debate of explaining the concept of Ubuntu even to Africans. African scholars have also entered the party of trying to explain the concept to their Western counterparts and in that way compromising the actual meaning of Ubuntu. ${ }^{4}$ The word Ubuntu refers to the humanness of people (Bediako 1997:2), the very intrinsic being as constituted by God in creation. It is an African ontological word describing what it means to be human in relation to others. Before the advent of Western white people and their philosophy, the term was purely understood as referring to humans as created by God and jointly bound to one another. It was never meant to be part of speculative philosophy. Ubuntu was understood to indicate the presence of characteristics such as kindness, charity, equality, love of one's neighbour and dispensing justice to others in human lives. There was no individual or independent existence without the creative inclusivity of God (Mbiti 1969:92). Ubuntu is anthropocentric and captures God as anthropomorphic. Individual life is surrounded by other people in the midst of the abounding presence of God. God is the explanation of human's origin and sustenance (ibid:92) and nature, environment and, in fact, the world exists for the benefit of all and their wellbeing. Tutu and Tutu (2010:6) translates Ubuntu as 'Goodness' -the essence of God's presence in human life. Its presence changes the way people see the world, the way they see others, and, more importantly, the way they see themselves. Consequently, it affects how people treat each other. ${ }^{5}$

The concept of Ubuntu is known intuitively rather than reflectively as Martin Buber argued in his work Transcendence and Relationality (1958:62). According to Martin Buber, transcendent experience which he calls 'pure experience' (Ubuntu in an African context) is based on encounter but not reflective thought but on active engagement. Ubuntu requires full participation in the life of the other; participatory experience rather than reflective experience. The emphasis in Ubuntu is on the betweenness ${ }^{6}$ that relate people to each other in mutuality (Kgatla 2013:2). This betweenness, as first coined by Martin Buber, calls love as expressed in human relationships and experience. Ubuntu requires humility, an act that requires the ego to deny its impetus to establish itself as primary and as the centre of human experience; overcoming the ego to establish foundational relationship with the other as used by Buber (1958:62).

To illustrate this further I employ Buber's metaphor of I-Thou relationships. Buber proposes two relationships that exist between humans and between humans and God: the I-Thou relationship and the I-It relationship (Kgatla 2013:9). The first relationship is that which exists between subject and subject and the second exists between subject and object. Love exists between I-Thou (subject to subject) relationships and is direct from subject to subject. Once humans are in an I-Thou relationship they can interact, share the unity of being, love one another, care, respect, and have commitment and responsibility for one another. Social justice takes shape in I-Thou relationships because humans not only appreciate the gift of being inclusive of the other, but see the space of 'inclusion' as an act of justice and peacemaking (Blair 2013:1). Creating space for the 'other', be it the poor, orphans, widows, the sick or the weak, sets the agenda for the common good. This is how Ubuntu in an African setting finds its roots.

The message of the Bible as recorded in the scriptures and its call to social justice has an affinity with the African view of Ubuntu. This article argues that Ubuntu as a form of reconciliation, forgiveness, telling the truth and treating fellow humans in a humane way is best expressed by African community (Ogbonnaya 1994:2). Toennies Ogbonnaya

5.Tutu and Tutu argues that Ubuntu is the sum total of human daily interaction in the spirit of live and let live (2010:7)

6.Martin Buber states that, in the beginning of our existence relation, as category of being, readiness, grasping form is defining moments of everything that follows (Ibid 1958:62) 
argues that African community (gemeinschaft in German) is embodied in a typical rural setting where personal relationships are characterised, explained and guided by traditional rules of loving innocently and loving without motive. ${ }^{7}$ Mutual affirmation and respect extending beyond immediate geographical proximity and immediate biology to include the natural connection of people everywhere is evident (ibid:2). In the same breath, Sandhya (ibid:3) argues that the principle of 'African Ubuntu', which was alive in the early church where people shared everything in common and no one was left in need, was the same spirit that guided the creation of the Truth and Reconciliation Commission in South Africa so that the people who had participated in brutal atrocities of apartheid could come forward, tell the truth, be forgiven and be welcomed back into South African society. Kgatla (2014:7) argues that the African National Congress Freedom Charter of 1955 also echoed African Ubuntu by declaring South Africa as belonging to all who lived in it. It is comforting when people in their natural setting know what is right and strive for that which is ideal. ${ }^{8}$

\section{Social justice is nurtured in relationships}

The creation story in the book of Genesis is the tale of relationships as indicated earlier. God created humans in his image and this proposed strong relations between Creator and creatures. This bond is not made with the rest of the created animals, they are merely creatures without the breath of God in them. They are not declared the living souls like humans are. Relationships presuppose close bonds, equality, sharing resources and responsibilities, and feeling for one another. Genesis 1:1-25 sets God as personal, rational (having intelligence and will, able to form plans and execute them), creative, competent to control the world he has made and morally admirable, in that all he created is good (http:/ / www.angelfire.com/md2/timewarp/buber). God is said to be the creator, sustainer and the ruler of the universe. In his sovereignty he chooses humans to be his co-workers in sustaining the universe and fulfilling his purposes in the world (Kane 1978:1988:86). The capacity of human creatures for communication and relationship both with God and humans are further facets of the image. Humans are thus 'souls' or 'spirit', that is, a personal, selfconscious, godlike creature with a godlike capacity for knowledge. They are morally upright. Although the Fall diminished God's image, humans still retain the image structurally and can still be addressed by and hear God (Buber 1958:26). They still retain the essence of the image and they can judge between good and evil. According to Buber (1958:26), humans are still capable of engaging in dialogue with each other on the one hand and with God on the other hand.

7.Jesus taught his followers what profit do they derive in loving those who love them They should rather love their enemies, those who do not love them.

8.The African concept of Ubuntu does not declare African people angels but, like the early church, they are struggling with the idea of social justice too.

\section{Anthropomorphism defines space in relationships}

Anthropomorphism is a normal phenomenon in Christianity as is the case with the African worldview. ${ }^{9}$ Anthropomorphic expressions found in the Bible narrow the distance between God and humans so that humans literally see God in their lives. Because they see him as they relate to him, they can access his love and justice. The limbs of the human body serve as an allegorical description of the acts of God as perceived by humans (Walter 1966:2). God is portrayed as seeing, hearing (Soc14), speaking, smelling and knowing. Scripture attributes love and hate, joy and delight, regret and sadness, pity and compassion, disgust and anger, revenge and other feelings to God. God's presence is real for Christians and they do what they do because of his working in them (Kgatla 2012:3). They speak of God as having a heart, face and hands, legs, feet and arms. All these wrap God in a package that is identified as personhood. Thus, God is a person and he is described almost as if he were some magnificent human interacting with humans on a daily basis. He is the exalted Father, the Brother of humans who comes to live among them and share their suffering with a view of freeing them from all evil. He comes even when uninvited and chooses the path of deliverance for society. He allows himself to be humiliated and crucified by the very people he has come to save. He becomes a champion of 'justice' to all including those who reject him. He has established a personal relationship with humans, energises them to work out his will and purpose in them (Kgatla 2012:5). The writer of Philippians 2:13 argues that God is working in us to will what is right, to want what is right and to desire what is right (Phillipians 2: 2-3; Gill n.d.).

God as person has an abiding relationship with humans and they experience the fullness of it every day of their lives and it works in them to produce the good that is there in their lives. Harmonious living together, peace, justice and caring that is in humans come from God. In his abiding relationship with human beings, God is portrayed by the Bible as always seeking the protection of the poor, the orphans and the marginalised within society. God's kingdom is just, inclusive, transformative and embracive. His kingdom balances and levels inequalities for the betterment of all.

For humans to be in this transforming and empowering relationship with the other, they should transcend the boundary of self. Kavanaugh (1981:4) speaks of 'the empty interior' when he refers to people without dynamic relationships to the other. When society loses its touch with the 'other' and lives exclusively for its own pleasure and desire it develops 'empty interior'. When the personal and interpersonal relationship disintegrates because of omnipresent immensity of material possession, humans lose their personhood and 'themselves' (Kavanaugh 1981:4). In a consumer society (where social justice is blurred by consumerism) Kavanaugh argues (1981:8) that human

9.Keith N. Schoville comments on the Baker's Evangelical Dictionary of the Biblical Theology (1996). 
passion, which can only be fulfilled by encountering persons, is channelled into possessions. The consequence of such a situation is betrayal and vulnerabilities of relationships. To be a person means to be in relation. To be a person is to relate and develop particular qualities of relating to the other (http://www.pocatelloumc.org/Pocatello_First_UMC_ website/Transcendence_Relation, accessed 25/02/2013). Humans ought to transcend their limits and boundaries and also understand that they should go beyond the limits to make contact with the other, with that which lies beyond themselves (ibid:1). God has set the example for humans by going beyond the narrow confines of the history of exclusion in order to approach and make contact with humans (Kgatla 2013:10). In order for one to be in relation, one must open up oneself and let others invade one's private space and make contact with them.

\section{Conclusion}

This article argues that true social justice is embedded in personal relationships. Where there are no interpersonal relationships and where there is asymmetrical power relations, justice is not possible. God in his creation established a close personal relationship with his creatures and literally nurtured the 'betweenness' to the point where he was crucified on the cross for the sake of them. He left this model of love and justice for his people to practise among themselves. The Bible creation stories carry this message. The four Gospels that narrate the life of Jesus on Earth carry this good news to the whole of humanity to emulate. To be human is to be in relationships and to be bound in love to one another.

The African concept of Ubuntu underlies this message of relationships. From primordial times Africans lived in close community and benefited from the close relationships of its members. Ubuntu has an affinity with the creation stories and shows how humans should relate to one another. Social justice can only be realised through human relationships such as espoused by the teachings of Ubuntu.

The article further argues that both Ubuntu and biblical teaching on social justice are expressed in anthropocentric and anthropomorphic terms. The closeness of the Creator and humans is a defining moment for their responsibilities to God and among themselves. It is only in human forms that people can relate to one another in an empowering way. God became human in Jesus Christ in order to save humanity. It was only in human form that he rendered justice to the world. The intimacy and union between Christ and his church as pronounced in the scripture shows how social justice should be pursued in life. The relationship between Christ and his followers is guided by tenderness and closeness that is determined by union of feelings, common destiny, interests, compassion, intimacy and love. Ubuntu as a concept that epitomises humanness is ever seeking restoration, healing, peace and life to all.

\section{Acknowledgements Competing interests}

The author declares that he has no financial or personal relationships which may have inappropriately influenced him in writing this article.

\section{References}

Altmann, W., 2013, Altmann report of the moderator of the central committee, World Council of Churches, Geneva.

Bediako, K., 1997, 'African in World Christianity in the 21st Century: Vision of the African Christian Future', African Theological Theological Fellowship, AkrofiChristaller Memorial Centre, Akropong-Akuapem, Accra, Ghana, 2 December, pp. 223-228.

Blair, M., 2013, Church and the diversity of God's creation and coming reign bonded with the marginalized for a just and inclusive church and world, World Council of Churches, Busan.

Buber, M., 1958, I and Thou, 2nd edn., Charles Scribner's Sons, New York.

Chipkin, I., 2013, The causes of ongoing social injustice. A Report for the RAITH Foundation, viewed 29 January 2016, from www.raith.org.za/.../The-Cause-ofSocial-Injustice-FINAL-15112013.do

Crossway Bibles, 2001, What does the Bible say about social justice? In Crossway Bibles, viewed 13 January 2014, from http://www.openbible.info/topics/social justice

Frazier, A.M., 1975, Issues in religion, D. van Nostrand Company, New York.

Gade, C.B.N., 2012, What is Ubuntu? Different interpretations among South Africans of African Descent, Department of Culture and Society, Aaarhus University, Aarhus.

Gill, J., n.d., John Gill's Exposition of the Bible. God works in us and out, viewed. n.d. from www.biblestudytools.com/commentaries/.../philippians-2-12.html

Johnson, W.R., 1994, Dismantling apartheid: A South African town in transition, Cornell University Press, London.

Kane, J.H., 1978, Understanding Christian missions, 4th edn., Baker Book House, Grand Rapids, MI.

Kavanaugh, J.F., 1981, Following Christ in a consumer society, Orbis Books, New York.

Kgatla, S.T., 2012, 'On a bumpy road: Historical survey (unity) talks between the Dutch Reformed Church in Africa and the Dutch Reformed before 1994', S T Kgatla in Studia Historia Ecclesiasticae September xxxvii (2), 205-224.

Kgatla, S.T., 2013, The transformational, intersectional and transcendental agenda of mission: Quest for a spirituality of the road in the Series of Association of Professor of Mission 2013, First Fruit Press, Wilmore, KY.

Kgatla, S.T., 2014, 'Songs of the harp from an African xylophone: Cries of deliverance. SHE Journal (Pending)', Studia Historiae Ecclesiasticae XXXIX(2), 223-235.

Kimmerle, H., 2001, 'Ubuntu and communalism in African philosophy and art in van den', H. Heuvel, M. Mangaliso \& L. van de Bunt (eds.), Prophecies and protest Ubuntu in global management, Unisa Edition, Pretoria, pp. 3-21.

Lanier, D.E., 2013, 'Who is my neighbor',? Biblical Illustrator Magazine, 9 April 13: $1-10$.

Mbiti, J.S., 1969, African religions and philosophy, Heinemann, London.

Novak, M., 2009, Social justice: Not what you think it is - Heritage Foundation, viewed 19 January 2016, from www.heritage.org/.../social-justice-not-what-yo

Ogbonnaya, A.O., 1994, On communitarian divinity: An African interpretation of the Trinity, Paragon House, New York.

Packer, J.J., 2013, Humanness: God made human beings in His image, Concise Theology, viewed 25 February 2013, http://www.oocities.org/gary_bee_za/ packer/humanness.htm

Ramose, M.B., 2001, An African perspective on justice and race. Polylog: Forum for Intercultural Philosophy 3, viewed 20 February 2016, from http://them.polylog. org/3/frm-en.htm

Rawls, J.A., 2001, Theory of justice, Harvard University Press, Cambridge. MA.

Robinson, M., 2014, What is social justice, Appalachian State University, Boone, NC.

Smith, A., 1864, Concept of social justice, Institute of Socio Economics (IAW), University of Hamburg, Cambridge MA.

The United Nations, 2009, The World day of social justice, viewed 13 January 2014 from, http://www.un.org/apps/news/story.asp

The Word in Life Study Bible, 1993, New Testament Edition, Thomas Nelson Publishers, Nashville, TN, pp. 340-341.

Tutu, D. \& Tutu, M., 2010, Made for goodness: And why this makes all the difference, Rider, London.

Walter, A., 1966, Baker's Evangelical dictionary of Biblical theology, Baker Book House Company, Grand Rapids, MI.

Wheaton, J.D., 2009, Christian social justice: "Life is just not fair" A Biblical view of social justice. http://thechristianworldview.com/tcwblog/at 2009

Worden, G., 2012, The making of modern South Africa, Wiley, Southern gate. 